\title{
GAMMA-RAY COMPUTED TOMOGRAPHY (CT) TECHNIQUE FOR TREE STEM INVESTIGATION
}

\author{
Bayu Azmi ${ }^{1}$ and Wibisono
}

1) Center for Isotopes and Radiation Application, BATAN Jl. Lebak Bulus Raya No 49, Jakarta 12440, Indonesia Corresponding author: bayuazmi@ batan.go.id

\begin{abstract}
ABSTRAK
TEKNIK COMPUTED TOMOGRAPHY (CT) SINAR GAMMA UNTUKINVESTIGASIBATANG POHON. Pepohonan memiliki peran yang penting dalam kehidupan manusia. Pohon-pohon dapat meningkatkan kualitas udara, menstabilkan temperatur, dan lain sebagainya. Akhir-akhir ini terdapat beberapa insiden pohon tumbang dan mengakibatkan korban jiwa. Investigasi batang pohon telah dilakukan dengan menggunakan teknik computed tomography (CT) sinar gamma untuk mempelajari kondisi bagian dalam dari batang pohon tersebut. Batang tersebut dipindai menggunakan tomografi generasi pertama yang disebut metode pemindaian parallel beam. 137Cs dengan aktivitas $80 \mathrm{mCi}$ memancarkan foton gamma yang menembus batang pohon dan diterima oleh detektor sintilasi $\mathrm{Nal}(\mathrm{Tl})$ pada sisi lainnya. Kedua sumber radiasi gamma dan detektor dikolimasi menggunakan timah hitam dengan diameter celahnya sebesar $5 \mathrm{~mm}$. Terdapat 128 data proyeksi yang kemudian direkonstruksi menjadi citra. Dibutuhkan waktu sekitar 522 menit untuk mendapatkan 128 data proyeksi tersebut. Citra hasil rekonstruksi menunjukkan bahwa terdapat variasi densitas dan dua lubang pada batang pohon tersebut dengan jelas. CT sinar gamma menjadi salah satu teknik yang menjanjikan untuk investigasi pohon. Pengembangan lebih lanjut dibutuhkan untuk mengurangi waktu pemindaian dan meningkatkan kualitas citra.
\end{abstract}

Kata kunci: Computed tomography, investigasi pohon, parallel beam, sinar gamma

\section{ABSTRACT}

GAMMA-RAY COMPUTED TOMOGRAPHY (CT) TECHNIQUE FOR TREE STEM INVESTIGATION. Trees have an important role in human life. Trees can improve air quality, stabilize ambient temperature, and so on. Nowadays there have been several incidents of fallen trees and resulted in fatalities. The tree stem investigation was done by gamma ray computed tomography (CT) technique to study the inside condition of the stem. The stem was scanned using the first generation of tomography called parallel beam scanning method. $80 \mathrm{mCi}$ of $137 \mathrm{Cs}$ emited gamma photons that penetrated the stem and received by the $\mathrm{NaI}(\mathrm{Tl})$ scintillation detector on the other side. Both gamma radiation source and detector were collimated using lead with $5 \mathrm{~mm}$ diameter of slits. There were 128 projections data which then reconstructed into image. It took about 522 minutes to collect the 128 projections data. The reconstructed image clearly showed there were density variations and two holes in the stem. Gamma-ray CT looks to be one of promising tree investigation technique. Further development is needed to reduce the scanning time and improve the image quality.

Keywords: Computed tomography, gamma-ray, parallel beam, tree investigation.

\section{INTRODUCTION}

Urban living has negative impacts, such as stacked housing and crowded living with poor air quality and thermal discomfort[1]. An important characteristic of tropical cities is urban greenery that creates shading along streets and in residential areas and can assist in the development of adaptation possibilities against climate change[2]. Vegetation is the most common method to alleviate the negative impacts of urban living[3]. Trees planting could improve air quality and stabilize ambient temperature also as street shading.

Nowadays there are several incidents of fallen trees that struct vehicles and houses even 
causing fatalities. Therefore, it is necessary to has a technique to study the density distribution on tree stem without damaging the tree. Tree stem density indicates how safe the tree is to keep growing. Cavities in the stem for example, it is significantly increasing the probability of the tree to collapse.

Tomography is an advanced technique that has been continuously developed and used for diagnostic purposes throughout last 40 years not only in medicine but also in industry, biology and civil engineering[4]. It started with the theoretical justification of the possibility of reconstructing the distribution of a certain parameter across a planar section of an object from its projections[5]. Computed tomography (CT) aims to reconstruct the spatial distribution of physical parameter of object to be imaged from its projections acquired by an imaging device using some energy flue such as x-ray, gamma-ray, neutron, electron and so on[6].

Several tree investigation experiments using CT that have been done before. Abdullah et. al. has designed mobile gamma-ray tomography system for early detection of basal stem rot in oil palm plantations[7]. Putri et. al. was conducted the evaluation of incenseresinous wood formation using sonic tomography at 2017[8]. Herve et. al. was using $\mathrm{x}$-ray computed tomography to conduct the density mapping of decaying wood[9], and several other experiments using tomography technique.

In this experiment, ${ }^{137} \mathrm{Cs}$ was used as the transmitter, $\mathrm{NaI}(\mathrm{Tl})$ scintillation detector as the receiver, and asoca tree stem as the object. It was scanned with parallel beam method, in which the radioisotope and the detector move simultaneously in a translation on a gantry flanking the object. Furthermore, the set of data was built into image using filtered back projection (FBP) algorithm.

\section{METHOD}

\section{Phantom}

The experiment was in labaoratory using a wood phantom. The phantom was asoca tree stem (Polyalthia longifolia). It has lush leaves that make it often planted as street shades in urban areas. This plant is also a medicinally important tree of the Indian system of medicine[10]. The wood was perforated with a certain size as shown in Figure 1. There are two holes with diameter of $80 \mathrm{~mm}$ and $40 \mathrm{~mm}$.

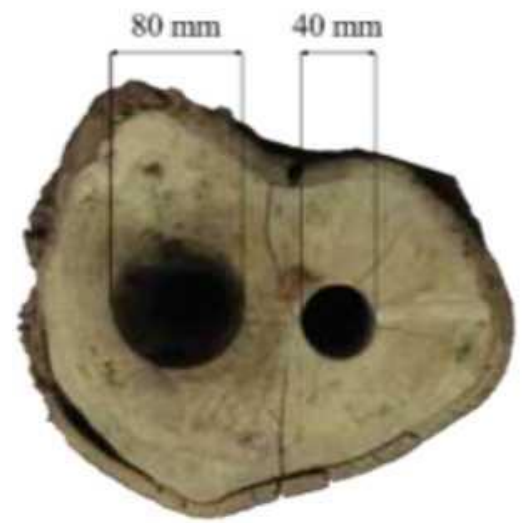

Figure 1. Wood phantom.

\section{Tomography System}

The experiment was conducted using the first generation of tomography called parallel beam scanning method. Azmi et. al. has built the automatic parallel beam gamma-ray tomography scanning system[11]. It consists of mechanical parts, computerized controlled module, a gamma ray source, a scintillation detector $\mathrm{NaI}(\mathrm{Tl})$, data acquisition and computer as shown in Figure 2. It was designed to conduct translational and rotational scan automatically.

The source and detector collimators move translationally on the gantry. The collimators slit has diameter of $5 \mathrm{~mm}$. Gamma-ray source collimator aimed to make gamma ray into narrow beam and for radiation safety purposes, whereas the detector collimator to block radiation scattering detected by detector. Translational scanning aims to obtain a projection data. The gantry is then through an angular increment until it has been rotated through 180 degree.

The interaction of gamma radiation with object will change theintensity which correlated to the properties of the object[12]. If gammaray are collimated into a narrow beam and allowed to strike a detector after passing through an absorber of variable thickness, the result should be simple exponential attenuation of the gamma ray[13]. It can be expressed by the Beer-Lambert law:

$$
\frac{I}{I_{0}}=e^{-\mu x}
$$

Where $I$ is the intensitv of radiation transmitted through the absorber. $I O$ is the intensity of initial radiation. $u$ is linear attenuation coefficient and $t$ 
is the thickness of the absorber.

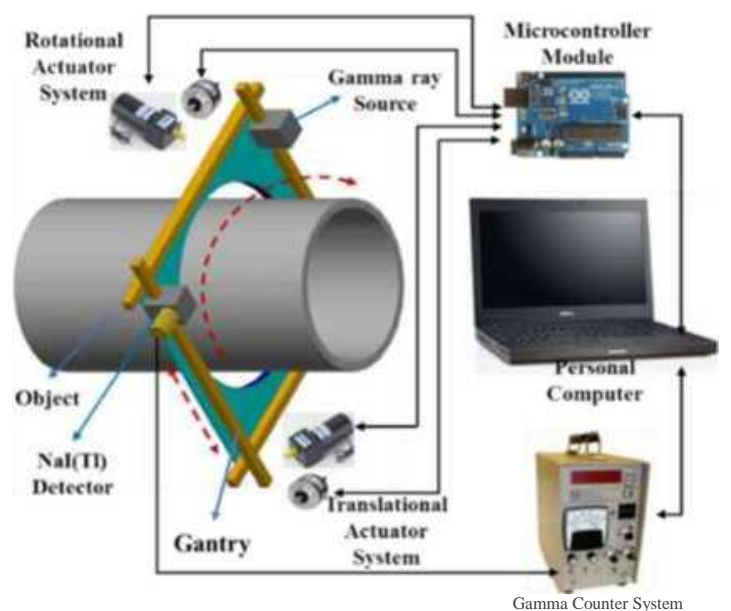

Figure 2. Gamma-ray tomography scanning system ${ }^{[11]}$.

${ }^{137} \mathrm{Cs}$ radiation source was used as the transmitter in the experiment. The Cs-137 is commonly used in nuclear gauging applications in industries because it has a long half-life, it does not scatter interference of photons of other energies and emits single clear photo peak [14]. It has a half-life of 30.23 years and decays by pure $\mathrm{p}$ - decay, producing ${ }^{137} \mathrm{Ba}$, which creates all the gamma-ray emissions with energy peak of $662 \mathrm{keV}$ [15].

While $\mathrm{NaI}(\mathrm{Tl})$ scintillation detector was used as the receiver. Scintillation detectors, such as, $\mathrm{NaI}(\mathrm{Tl})\left(3.76 \mathrm{~g} / \mathrm{cm}^{3}\right)$ BGO (Bi4Ge3O12, $7.13 \mathrm{~g} / \mathrm{cm}^{3}$ ), LYSO (Lu 0.6Y1.4SiO0.5: Ce, 5.37 $\left.\mathrm{g} / \mathrm{cm}^{3}\right)$, LSO $\left(7.35 \mathrm{~g} / \mathrm{cm}^{3}\right)$ and GSO $\left(6.71 \mathrm{~g} / \mathrm{cm}^{3}\right)$ are widely used in tomography applications [16]-[18].

\section{EXPERIMENT}

The phantom was scanned in crosssection. It was placed in the middle of the gantry as shown in Figure 3. The translational scanning was set to count the gamma photon every $5 \mathrm{~mm}$ based on the diameter size of the collimators slits. ${ }^{137} \mathrm{Cs}$ with activity of $2.96 \mathrm{GBq}$ was used as the transmitter. The radiation counted by the detector are about 20000 CPS at air medium (does not hit the phantom). Therefore, counting time is determined every 1 second.

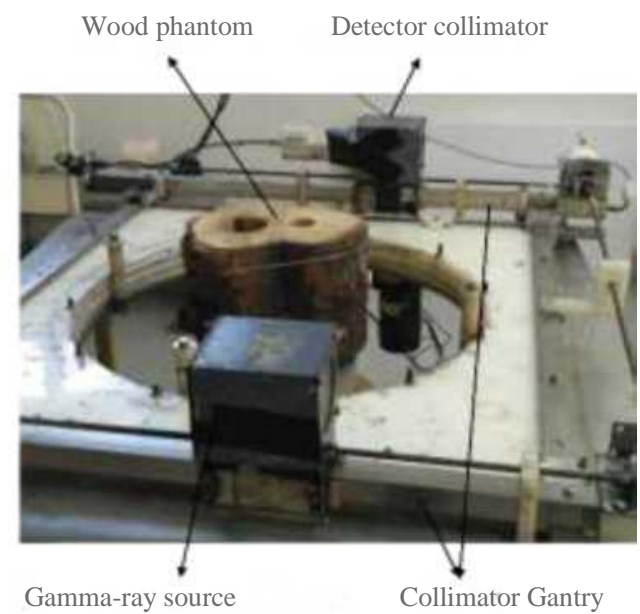

Figure 3. Experiment setup.

The projection angular increment was 1.40625 degree (128 projections in 180 degree). It takes about 522 minutes to perform $5 \mathrm{~mm}$ translational step and 128 projections. The 5 $\mathrm{mm}$ translational move made the pixel size of reconstruction image was $5 \mathrm{~mm}$ x $5 \mathrm{~mm}$. There were 62 translational steps $(31 \mathrm{~mm})$ in every set of translational scans. It depends on the size of the object. Larger object needs more translational steps.

\section{RESULT AND DISCUSSION}

The data were built into images using Filtered Back Projection (FBP) algorithm. The reconstructedimage from 128 projections was compared to the phantom as shown in Figure 4. The data were made into 16 projections, 32 projections, 64 projections, and 128 projections. The reconstructed images as shown in Figure 5.

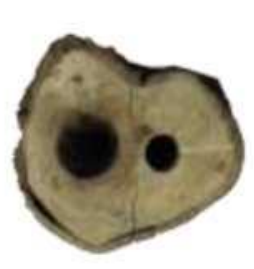

(a)

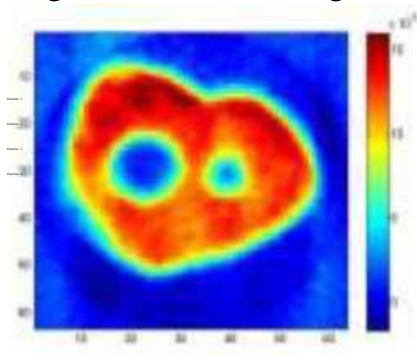

(b)
Figure 4. (a) phantom and (b) reconstructed image of 128 projections.

The reconstructed image shows that it was fit with the object (phantom). The system is able to recognize the cavities (holes) inside the phantom. Density variations in phantom can be observed based on the image. The blue color 
represents the lowest density (air) and the reddist color represents the highest density (some area of phantom).

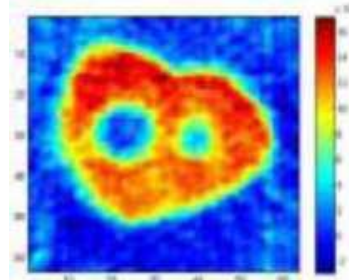

(a)

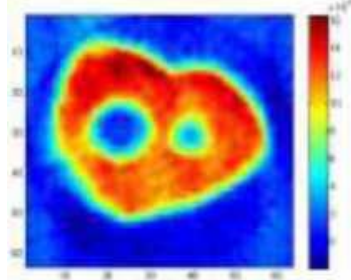

(c)

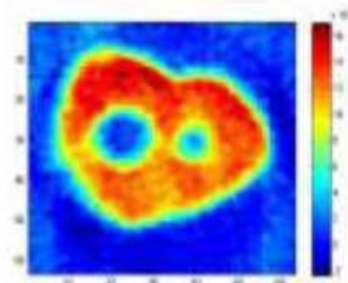

(b)

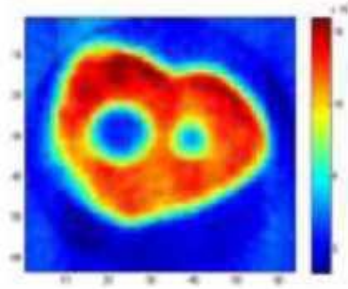

(d)
Figure 5. Reconstructed images, (a) 16 projections, (b) 32 projections, (c) 64 projections, and (d) 128 projections.

The number of projections affects the contrast quality of the reconstructed image. More projections number produce higher contrast. It is mean the image could recognize the deferences of density better. The problem is the scanning time. It must be compromize between the scanning time and the results.

Another way to get better result regarding to cavities recognition is by filtering the low density as show in Figure 6.

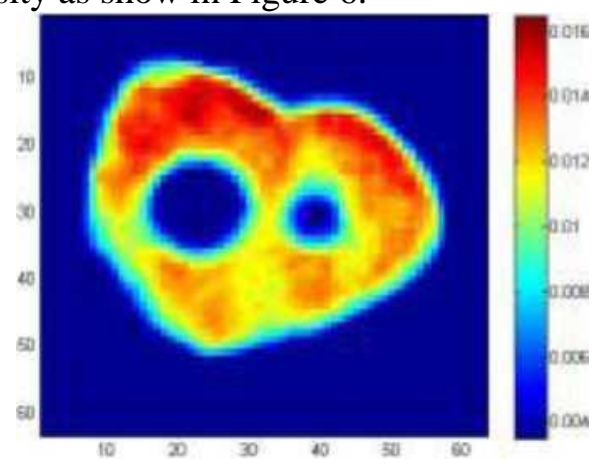

Figure 6. Low density filtered image.

\section{CONCLUSION}

It was proved that gamma-ray $\mathrm{CT}$ is suitable technique for tree investigation. The images are able to show the density distribution inside phantom. The holes inside the phantom also clearly observed. Based on the colimator slit size and the translation steps, the pixels size represents $5 \mathrm{~mm}$ x $5 \mathrm{~mm}$ actual dimension. The scanning time is too long because of using single detector. Therefore, it is necesarry to develop the multi-detector system to shorten the scanning time.

\section{ACKNOWLEDGEMENTS}

The authors would like to acknowledge the Center for Isotopes and Radiation Aplication, BATAN for supporting this experiment. We also would like to thank Maulana Ihsan, Burhanuddin Ahmad, and Fitria Yunita Dewi for their assistance during the experiment.

\section{REFERENCES}

1. C. Yuan, L. Norford, and E. Ng, "A semiempirical model for the effect of trees on the urban wind environment," Landsc. Urban Plan., vol. 168, no. July, pp.84-93, 2017.

2. L. V. de Abreu-Harbich, L. C. Labaki, and A. Matzarakis, "Effect of tree planting design and tree species on human thermal comfort in the tropics," Landsc. Urban Plan., vol. 138, pp. 99109,2015.

3. Q. Zhao, D. J. Sailor, and E. A. Wentz, "Impact of tree locations and arrangements on outdoor microclimates and human thermal comfort in an urban residential environment," Urban For. Urban Green., vol. 32, no. September 2017, pp. 81-91, 2018.

4. D. N. The Duy, N. H. Quang, P. Van Daon, B. T. Duy, and N. Van Chuan, "A Third Generation Gamma-ray Industrial Computed Tomography Systems for Pipeline Inspection," J. Teknol., vol. 17, pp. 49-53, 2015.

5. S. V. Chakhlov, S. P. Osipov, A. K. Temnik, and V. A. Udod, "The current state and prospects of X-ray computational tomography," Russ. J. Nondestruct. Test., vol. 52, no. 4, pp. 235-244, 2016.

6. S. Tang, Z. Qiao, J. Wu, and Y. Zhu, "Polar coordinate interior tomography," Optik (Stuttg)., vol. 168, pp. 313-322, 2018.

7. J. Abdullah, H. Hassan, M. R. Shari, S. Mohd, M. Mustapha, A. A. Mahmood, S. Jamaludin, M. R. Ngah, and N. H. Hamid, "GammaScorpion: mobile gamma-ray tomography system for early detection of basal stem rot in oil palm plantations," Opt. Eng., vol. 52, no. 3, p.036502,2013. 
8. N. Putri, L. Karlinasari, M. Tuijaman, I. Wahyudi, and D. Nandika, "Evaluation of incense-resinous wood formation in agarwood (Aquilaria malaccensis Lam.) using sonic tomography," Agric. Nat. Resour., vol. 51, no. 2, pp. 84-90, 2017.

9. V. Herve, F. Mothe, C. Freyburger, E. Gelhaye, and P. Frey-Klett, "Density mapping of decaying wood using X-ray computed tomography," Int. Biodeterior. Biodegrad., vol. 86, pp. 358-363, 2014.

10. P. Sharma, S. Sharma, S. Yadav, A. Srivastava, A. Varma, K. Luhana, and N. Shrivastava, "Categorization of Saraca asoca and Polyalthia longifolia, using chemical and genetic fingerprinting associated with multivariate statistical analysis," J. Appl. Res. Med. Aromat. Plants, no. May 2017, pp. 0-1, 2018.

11. B. Azmi, Wibisono, and A. H. Saputro, "Portable Gamma Ray Tomography System for Investigation of Geothermal Power Plant Pipe Scaling," 2017 15th Int. Conf Qual. Res. Int. Symp. Electr. Comput. Eng., pp. 159-163, 2017.

12. S. Sugiharto, "On-line Diagnosing on Trayed Column of Etylene Plant Using Gamma Ray Scanning," Atom Indones., vol. 38, no. 3, pp. 138-146, 2012.

13. Glenn F. Knoll, Radiation Detection and Measurement, 2nd ed. John Wiley \& Sons, Ltd, 2010.

14. T. Al-Juwaya, N. Ali, and M. Al- Dahhan, "Investigation of crosssectional gas-solid distributions in spouted beds using advanced non- invasive gamma-ray computed tomography (CT)," Exp. Therm. Fluid Sci., vol. 86, pp. 37-53, 2017.

15. M. K. Al Mesfer, A. J. Sultan, and M. H. AlDahhan, "Impacts of dense heat exchanging internals on gas holdup cross-sectional distributions and profiles of bubble column using gamma ray Computed Tomography (CT) for FT synthesis," Chem. Eng. J., vol. 300, pp. 317-333,2016.

16. C. M. Pepin, P. Berard, A. L. Perrot, C. Pepin, D. Houde, R. Lecomte, C. L. Melcher, and H. Dautet, "Properties of LYSO and recent LSO scintillators for phoswich PET detectors," IEEE Trans. Nucl. Sci., vol. 51, no. 3 II, pp. 789795, 2004.

17. G. A. Johansen, Radioisotope Gauges for Industrial Process Measurements. John Wiley \& Sons, Ltd, 2004.
18. P. A. S. Vasquez, C. H. De Mesquita, G. A. C. LeRoux, and M. M. Hamada, "Methodological analysis of gamma tomography system for large random packed columns," Appl. Radiat. Isot., vol. 68, no. 4-5, pp. 658-661, 2010. 
JURNAL FORUM NUKLIR (JFN) VOLUME 12, NOMOR 2, NOVEMBER 2018 